\title{
ANALYSIS OF LANDFILL GAS CONTRIBUTORY FACTORS IN SANITARY LANDFILLS
}

\author{
UDC 628.1.045(497.11)
}

\author{
Biljana Nikolić $^{1}$, Lidija Milošević ${ }^{2}$, Emina Mihajlović \\ ${ }^{1}$ Higher Technical Professional School in Zvečan, Serbia \\ ${ }^{2}$ University of Niš, Faculty of Occupational Safety, Serbia
}

\begin{abstract}
Waste disposal is an element of integrated waste management. Properly designed projects for landfill construction ensure safe waste disposal with minimal environmental impact. The first part of this paper discusses and analyses waste management and landfills in Serbia. The second part describes the factors contributing to landfill gas ( $L F G)$ generation. The influence of several factors on $L F G$ generation is shown on the basis of measurements of LFG components concentrations and of the analysed wastewater samples taken from "Pirot" Regional Sanitary Landfill. Depending on the contributory factors, provision of optimal conditions at the landfill accelerates waste decomposition, in turn producing larger quantities of $L F G$, with the ultimate goal of proper controlled LFG management. The paper presents guidelines for controlled LFG management, the implementation of which would automatically meet the requirements and recommendations of both domestic and European legislation.
\end{abstract}

Key words: waste, sanitary landfill, landfill gas, landfill leachate, methane, contributory factors

\section{INTRODUCTION}

The issue of waste management has existed since the earliest human settlements, but it is particularly prominent in present-day urban environments. With the increase in population density, caused by population rise and their gravitating toward large cities, and with the rapid industrial growth, modern humans produce much more waste than ever before in the history of humankind. Scientific and technological progress has led to the creation of new and diverse products, which, due to a higher standard of living and changed consumer habits, have a considerably shorter lifetime than their predecessors and consequently turn into waste much sooner. This significantly complicates waste

Received October 2, 2019 / Accepted December 3, 2019

Corresponding author: Biljana Nikolić

Higher Technical Professional School, Nušićeva 6, 38227 Zvečan, Serbia

E-mail: biljananikolic02@gmail.com 
collection and treatment. On the other hand, like never before, waste represents a valuable resource, which can be used to produce energy or other new products for various purposes.

In addition to climate change and continuous loss of biodiversity, waste is one of the biggest problems of modern humankind. What separates waste from other pollutants is the fact that it is produced by every person on the planet, to a greater or lesser extent.

Waste composition and quantity vary substantially depending on the factors such as geographical and climatic characteristics, economic status, type and range of industrial activities, social and demographic characteristics of a community, the time of year, and many more.

Due to the ever-increasing complexity of waste composition caused by the development of new products and materials, waste collection and treatment methods also become increasingly complex by the day.

\section{WASTE AND LANDFILL CHARACTERISTICS}

Waste is a complex mixture of predominantly solids, comprising materials of different composition and durability. According to the European Directive 2008/98/EC and the Serbian legislation (Law on Waste Management) regarding waste, waste is defined as "any substance or object which the holder discards or intends or is required to discard" $[1,2]$. In that sense, waste represents the loss of material and energy, as it requires additional effort for collection, treatment, and final disposal. Yet, waste can also be viewed as a valuable well of both material and energy resources.

The Law on Waste Management contains the following classification of waste according to its place of generation:

- municipal waste - household waste and any other waste that resembles household waste in nature or composition;

- commercial waste - waste generated in companies and institutions whose entire or partial activity involves trading, services, office work, sports, recreation, or entertainment;

- industrial waste - waste from any industry or an industrial location, except tailings and the accompanying mineral raw materials from mines and quarries.

According to its hazardous properties, which affect human and environmental health, waste is classified into [2]:

- inert waste - waste that is not susceptible to physical, chemical, or biological changes, that is insoluble, incombustible, or without any other physical or chemical reaction, that is non-biodegradable, and that does not pollute the environment or threaten human and animal health;

- non-hazardous waste - waste that does not have the characteristics of hazardous waste;

- hazardous waste - waste that can threaten the environment and human health due to its origin, composition, or concentration of hazardous materials and that possesses at least one of the characteristics determined by special rules and regulations, which includes the packaging. 
According to its origin, waste can be classified as organic and inorganic. Even though there are other classifications of waste, it is evident that all waste types can be included in at least one of the aforementioned groups. Waste can be composed of glass, plastic, paper, cardboard, metal, leftover food, textile, wood, etc. There are also special waste types, such as tyres, products containing asbestos, small and car batteries, waste oils, and electric and electronic devices. Waste composition greatly depends on a variety of factors, such as economic development, cultural norms, geographic location, types of energy sources used, as well as climatic factors. Generally, in economically well-developed and medium developed countries there is a higher percentage of wastes such as paper, plastic, and aluminium, whereas in developing countries organic and biodegradable waste has a higher share (from $40 \%$ up to as much as $85 \%$ ) [3].

The waste deposited in landfills is potentially flammable and can cause both surface and sub-surface fires. The most highly flammable materials in a landfill include paper, plastic, parts of green waste, and specific materials from the manufacturing process. Landfill gas (LFG) is a flammable and potentially very harmful mixture of methane, carbon dioxide, and other accompanying compounds [4].

Inadequate waste management is one of the biggest environmental issues in Serbia. Results from numerous studies indicate that there are over 3,500 landfills in Serbia, of which only 180 are official municipal landfills, while others are mostly illegal dump sites. The results also show that Serbia generates 2,374,375 tonnes of waste annually, or an average of $0.87 \mathrm{~kg}$ per capita daily. The most prominent waste category is green waste $(12.14 \%)$ and other bio-degradable waste $(37.62 \%)$, followed by plastic $(10 \%)$ and its subcategory - plastic bags (4-7\%). Paper, glass, and cardboard constitute $2 \%$ to $10 \%$. Waste composition is fairly similar in other developing countries, as well. Serbia has ten built regional landfills, which cover about $22 \%$ of the total amount of waste in Serbia, and a number of municipalities and cities are still in the planning and project development stage [5].

Disposal of municipal waste is the simplest and cheapest method of waste treatment, the main goal being long-term sustainable waste disposal aimed at protecting the environment and human health.

Landfills are specially selected locations for technical and technological organized disposal and treatment of solid municipal waste. Structurally, they are phase-heterogeneous systems (solid, liquid, and gaseous phase) that contain a large number of materials with different physicochemical properties on a relatively small surface area [6].

Design, construction, use, and closure of landfills are regulated by the law. Such systems can be home to numerous chemical reactions, primarily acid-base, oxidationreduction, and adsorption reactions, which produce complex compounds [7]. The strong reactive potential is due to the fact that most of the materials present - reactants - are in the solid phase. There are two phases in the lifetime of a landfill. The first is the period of intensive chemical activity (up to 10 years), while the second is a much less active period, but a much longer one and can last for decades. It is assumed that a landfill reaches a stable physical and chemical state at the end of the second phase. Therefore, it is important to organize landfills in such a way as to maximally accelerate their processes and to facilitate control over products created in those processes.

Unorganized landfills are landfills without gas wells for LFG extraction and treatment, where landfill leachate is discharged without previous treatment and waste is 
deposited directly over the soil, without previous hydro-isolation of the landfill bottom. Such landfills are common in developing countries and act as environmental polluters by emitting pollutants into surface and ground water, as well as into air and soil. On the other hand, sanitary landfills are organized facilities in which solid waste is deposited in a manner that reduces a negative environmental impact. These landfills are complex built structures containing complex systems of interconnected components and subsystems that act in conjunction to enable decomposition and stabilization of deposited waste over time [8]. Sanitary landfills are usually suitable for all climates and they generate highly toxic leachate and considerable amounts of LFG. Leachate and LFG released from landfills can pollute the environment.

\section{LANDFILL GAS CONTRIBUTORY FACTORS}

LFG usually consists of methane $\left(\mathrm{CH}_{4}\right)$, carbon dioxide $\left(\mathrm{CO}_{2}\right)$, water vapour, nonmethane hydrocarbons (NMHCs), and other compounds (Table 1). It is estimated that solid municipal waste contains $75 \%$ of organic matter, which generates an average of $0.005 \mathrm{~m}^{3} / \mathrm{h}$ of LFG per one kilogram of waste.

Table 1 Landfill gas composition [9]

\begin{tabular}{lcc}
\hline LFG constituent & $\begin{array}{c}\text { Concentration } \\
{\left[\%_{\text {vol }}\right]}\end{array}$ & $\begin{array}{c}\text { Maximum concentration } \\
{\left[\%_{\text {vol }}\right]}\end{array}$ \\
\hline Methane & 63.8 & 88.0 \\
Carbon dioxide & 33.6 & 89.3 \\
Nitrogen & 2.4 & 87.0 \\
Oxygen & 0.16 & 20.9 \\
Hydrogen & 0.05 & 21.5 \\
Higher alkanes & $<0.05$ & 0.07 \\
Ethylene & 0.018 & - \\
Unsaturated hydrocarbons & 0.009 & 0.048 \\
Ethane & 0.005 & 0.0139 \\
Acetaldehyde & 0.005 & - \\
Butane & 0.003 & 0.023 \\
Propane & 0.002 & 0.0179 \\
Carbon monoxide & 0.001 & 0.09 \\
Helium & 0.00005 & - \\
Halogenated compounds & 0.00002 & 0.032 \\
Hydrogen sulphide & 0.00002 & 35.0 \\
Organosulphur compounds & 0.00001 & 0.028 \\
Alcohols & 0.00001 & 0.128 \\
Other & 0.00005 & 0.023 \\
\hline
\end{tabular}

The first three phases of deposited waste decomposition last relatively short - from 180 to 200 days. In the third acidic and anaerobic phase, $\mathrm{CO}_{2}$ is still released, while acids are produced with great intensity. Also, the microbiological activity of acetic acid results in the formation of methane $\left(\mathrm{CH}_{4}\right)$. In the fourth, methane phase, the landfill matures, i.e. there is now a balance of anaerobic processes, within which $\mathrm{CO}_{2}$ and $\mathrm{CH}_{4}$ 
are released relatively steadily [5]. The composition of LFG constituents will change depending on the waste decomposition phase, as shown in Figure 1.

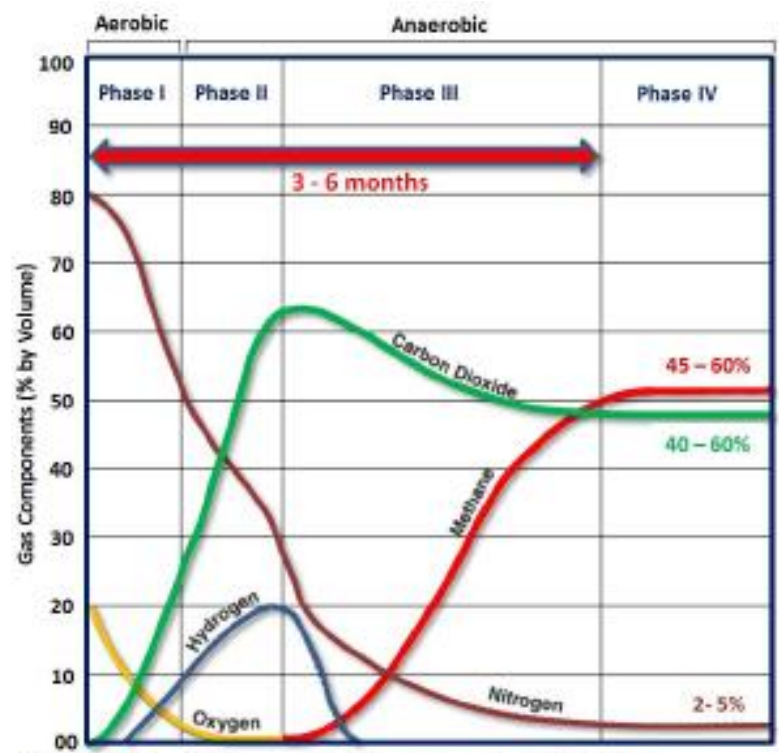

Fig. 1 Landfill gas composition during the phases of municipal waste decomposition [10]

Numerous factors influence LFG generation, including waste composition, waste age, temperature, presence of oxygen, moisture content, $\mathrm{pH}$ value, leachate recirculation, presence of hydrogen, nutrients, and sulphates, pressure, and the properties of landfill cover [11].

\subsection{Waste composition}

The scope of biodegradation depends on the availability and the size of biodegradable share of waste mass. The composition of organic waste components, primarily cellulose, proteins, and lipids, instigates waste decomposition, which in turn leads to LFG generation. Decomposition period of deposited organic matter can be rapid (3 months to 5 years) or slow (5 to 25 years) [12]. The lignin/cellulose concentration ratio negatively affects methane generation due to the presence of easily degradable carbon and negatively correlates with waste age, which shows that methanogenic waste is more active in gas production [13]. Figure 2 shows the morphological composition of municipal waste at "Pirot" Regional Sanitary Landfill. Considering that $23 \%$ of the waste is organic municipal household waste and $51 \%$ is waste from public areas (green waste, leftover food, boxes, paper), it can be concluded that about $74 \%$ of organic waste decomposes easily. 

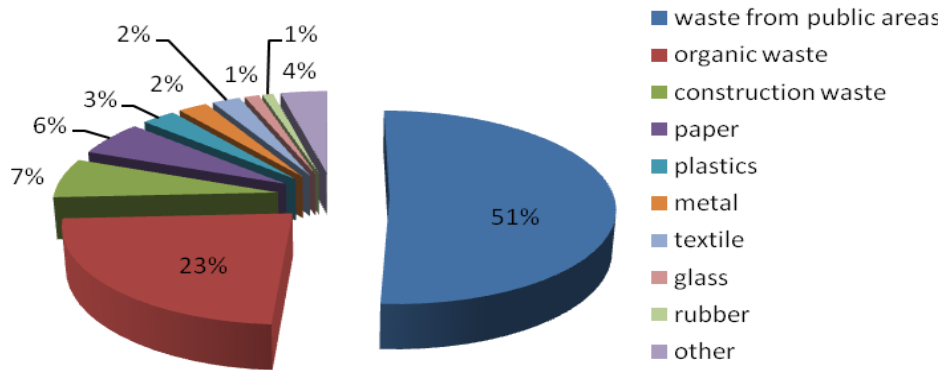

Fig. 2 Morphological composition municipal waste at "Pirot" Regional Sanitary Landfill [12]

\subsection{Waste age}

More recently deposited waste will generate more LFG than the waste that has been lying at the landfill for some time. Landfills usually generate considerable amounts of LFG within the period of one to three years. The maximum LFG generation is reached within the period from five to seven years after deposition. Various portions of a landfill can simultaneously go through different waste decomposition phases, depending on waste age. Twenty years after landfill closure, LFG generation is minimal, with only traces of it left; however, smaller amounts of gas can be generated even 50 years from closure [14].

In this study, a simulation using LandGEM v.3.02 software was carried out to calculate the maximum volume emission of LFG, which amounts to $5,064 \times 10^{6} \mathrm{~m}^{3} / \mathrm{god}$ and is expected to occur in 2034, after which LFG emissions will gradually decrease (Figure 3). Ten years after reaching its maximum value, LFG emissions will decrease by $30 \%$, while twenty years after, it will decrease by more than $50 \%$ [12].

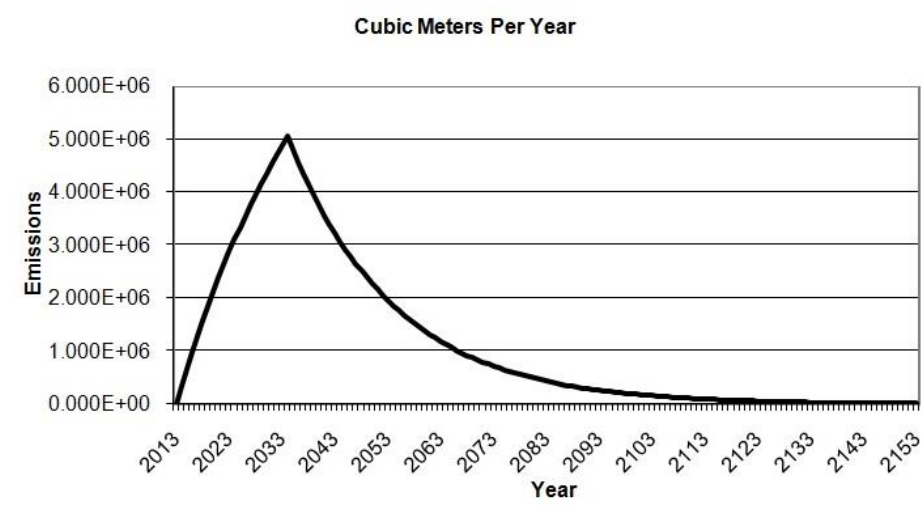

Fig. 3 Prediction of total LFG volume emission "Pirot" Regional Sanitary Landfill [12] 


\subsection{Temperature}

The growth of microorganisms and the formation of their metabolic products are the result of a series of biochemical reactions that depend on the temperature within the cells. Since microorganism cells are unable to thermally self-regulate, cellular temperature directly depends on environmental temperature. Higher temperature stimulates bacterial activity, which directly leads to increased gas generation [5, 12]. On the other hand, lower temperature inhibits bacterial activity, so gas generation sharply decreases if the temperature drops below $10^{\circ} \mathrm{C}$. Weather changes significantly affect shallow landfills, because the bacteria are not sufficiently isolated to resist temperature changes, unlike deep landfills, where waste is covered by thick layers of soil. Covered landfills maintain stable temperature, which increases LFG generation. Bacterial activity releases heat, stabilizing the landfill temperature between $25^{\circ} \mathrm{C}$ and $45^{\circ} \mathrm{C}$. Nevertheless, temperatures up to $70^{\circ} \mathrm{C}$ were recorded in some landfill bodies (Table 2). Laboratory experiments demonstrated that a temperature increase from $20^{\circ} \mathrm{C}$ to $30^{\circ} \mathrm{C}$ and then to $40^{\circ} \mathrm{C}$ substantially increases methane generation [15].

Table 2 Bacterial activity at specified temperatures during waste decomposition [16]

\begin{tabular}{lc}
\hline Type of bacteria & Temperature $\left[{ }^{\circ} \mathrm{C}\right]$ \\
\hline Psychrophiles & $5-25$ \\
Mesophiles & $30-35$ \\
Thermophiles & $50-60$ \\
Hyperthermophiles & $>65$ \\
\hline
\end{tabular}

Figure 4 shows the measured temperature values at "Pirot" Regional Sanitary Landfill for July 2015 . Since the temperature ranges from $29.3^{\circ} \mathrm{C}$ to $38.5^{\circ} \mathrm{C}$, it can be concluded that mesophilic bacteria are active inside the landfill body.

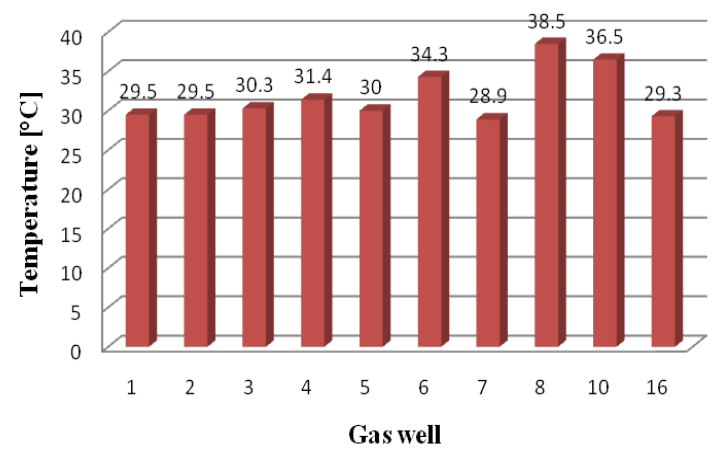

Fig. 4 Measured landfill gas temperatures at "Pirot" Regional Sanitary Landfill [12]

\subsection{Presence of oxygen}

Methane generation begins after all the oxygen has been depleted. The presence of oxygen is considered an inhibiting factor for methane generation [17]. The more oxygen there is in a landfill, the longer aerobic bacteria decompose the waste. If the 
waste is only partially covered with a layer of soil or if it is frequently mixed, there will be more oxygen and aerobic bacteria will live longer and keep producing carbon dioxide in water. Anaerobic bacteria begin with production only when aerobic bacteria have used up the oxygen, so any presence of oxygen in the landfill would decelerate methane generation. Changes in atmospheric pressure can also cause the atmospheric oxygen to be transferred to the landfill. This option is highly likely in layers at shallower depths, which would then undergo the aerobic phase of waste decomposition.

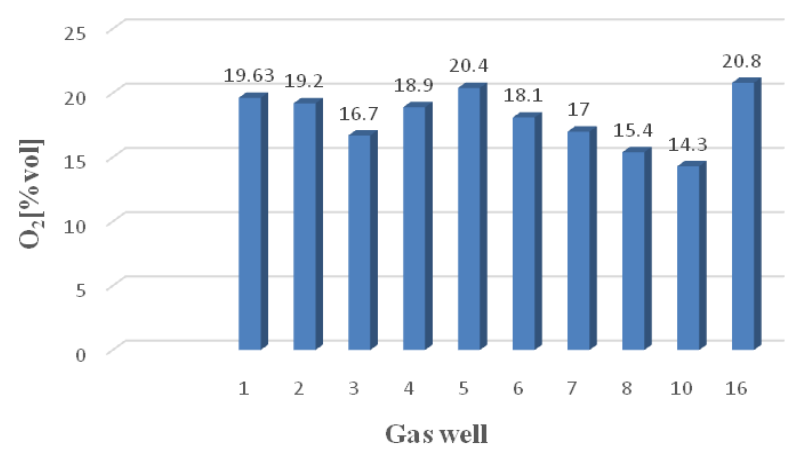

Fig. 5 Measured oxygen concentrations at "Pirot" Regional Sanitary Landfill [12]

Figure 5 shows the measured oxygen concentrations for July 2015. It is noticeable that oxygen concentrations are higher in all gas wells, which means that aerobic bacteria decompose waste longer inside the "Pirot" Regional Sanitary Landfill body.

\subsection{Moisture content}

Processes of infiltration, transpiration, and evaporation continuously influence one another, thus repeatedly redistributing moisture and affecting the water balance inside the landfill. Landfill waste acts as a giant sponge, through which water moves and from which water can escape to ground water, to the atmosphere (as water vapour), or to the bottom of the landfill as leachate. When the water descends during drainage (downward gravity drainage) or distribution, it can move under the influence of capillary effects or in the form of water vapour. A landfill is a multi-layered body due to waste deposition in horizontal layers and daily covering with horizontal layers of soil [18]. Such a structure impacts the movement of moisture within the soil. Water does not migrate in a direct vertical direction, but follows the complex laterally branching capillary spaces. Cover layers form priority flows, which can limit the contact time between water and waste and thus limit the amount of extracted pollutants. A certain amount of polluting leachate reaches the bottom of the landfill and it can potentially drain into ground or surface waters, diminishing their quality.

Water presence and increase in the landfill increases gas generation, because moisture stimulates the development of bacteria and the transport of nutrients to all parts of the landfill [19]. Water constitutes $80-90 \%$ of microorganism mass. Moisture content of $40 \%$ and higher leads to maximum LFG generation. Waste compactness can 
help reduce gas generation, because the increased density of the landfill reduces water infiltration into every waste layer. LFG generation is greater if there is heavy precipitation and if there are leaks in the cover layers, which allow additional water to flow into the landfill, as shown in Figure 6.

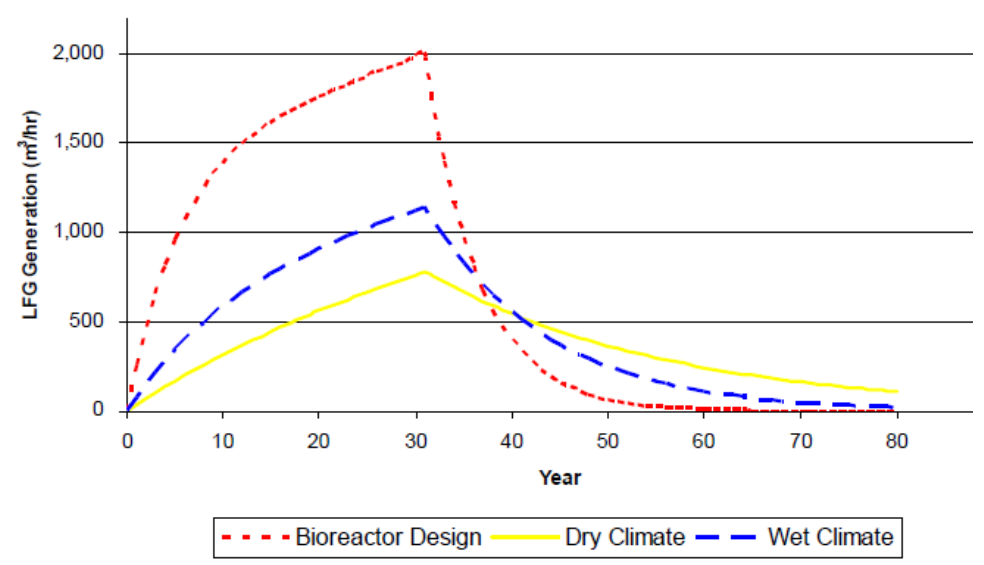

Fig. 6 Influence of moisture on landfill gas generation [20]

\section{6. pH value}

Decomposition processes of a municipal sanitary landfill can be generally divided into four phases. The first, initial, phase is characterized by aerobic processes, which involve a heavy expenditure of atmospheric pressure to enable oxidizing hydrolysis of carbohydrates, proteins, and fats from organic waste. The acidity of the environment slowly increases during this phase, while $\mathrm{pH}$ value decreases, which also enables accelerated dissolution of inorganic components. The second phase is a transition phase, in which the decomposition of organic substances gradually becomes anaerobic $[12,18]$. As early as the second phase, the acidity of the environment locally decreases to as low as $\mathrm{pH}$ 5. This process enriches the landfill leachate with numerous inorganic ions, such as cations of $\mathrm{Ca}, \mathrm{Mn}, \mathrm{Fe}, \mathrm{Cu}, \mathrm{Zn}, \mathrm{Cr}$, etc., and anions, such as sulphate, chloride, nitrate, nitrite, phosphate, and other anions. Higher fatty acids decompose to acetic acid $\left(\mathrm{CH}_{3} \mathrm{COOH}\right)$ through beta-oxidation, while at the same time significant amounts of $\mathrm{CO}_{2}$ and $\mathrm{H}_{2}$ are generated and nitrogen from the air is intensively consumed.

\subsection{Leachate recirculation}

Leachate recirculation positively affects the generation of methane $\left(\mathrm{CH}_{4}\right)$, provided the leachate has an adequate $\mathrm{pH}$ value and composition, as these properties are the main factors of methane generation. Leachate recirculation also positively affects the growth and activity of methanogen population due to increased moisture content [21]. To accelerate the stabilization of sanitary landfills, a variety of methods and technological procedures have been developed, the most notable of which include air pumping and 
leachate recirculation, which provides moisture for the waste and stimulates the biodegrading activity of microbes.

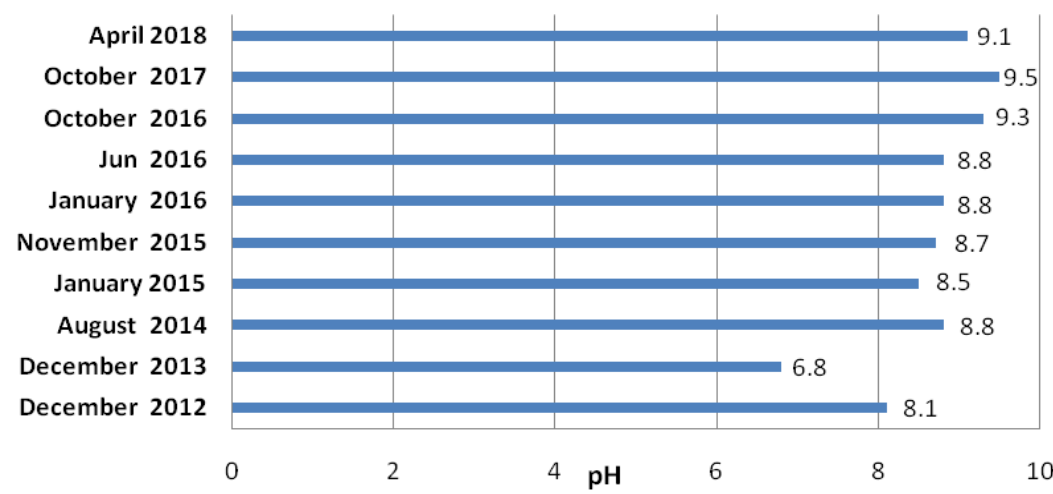

Fig. 7 Measured pH values of waste water at "Pirot" Regional Sanitary Landfill

Microorganisms are the most active in areas of optimal $\mathrm{pH}$ values for the key enzymes. There are minimum and maximum $\mathrm{pH}$ values at which microorganisms are still able to survive. Methanogenic bacteria function optimally within the $\mathrm{pH}$ range of 6 to 8 . Studies have shown that methane generation subsides when $\mathrm{pH}$ drops below 6 . Accumulation of hydrogen $\left(\mathrm{H}_{2}\right)$ and acetic acid $\left(\mathrm{CH}_{3} \mathrm{COOH}\right)$ reduces $\mathrm{pH}$ values, which inhibits the activity of methanogenic bacteria and thus limits methane generation. Microorganisms handle $\mathrm{pH}$ changes better than temperature changes [22-28].

Figure 7 shows the measured $\mathrm{pH}$ values of waste water at "Pirot" Regional Sanitary Landfill. The $\mathrm{pH}$ values range from 6.8 to 9.51 , which means that the methanogens are functioning properly and that methane generation is intensive.

\subsection{Presence of hydrogen}

Fermentative and acetogenic bacteria produce hydrogen $\left(\mathrm{H}_{2}\right)$. At low hydrogen partial pressure, fermentative bacteria produce hydrogen $\left(\mathrm{H}_{2}\right)$, carbon dioxide $\left(\mathrm{CO}_{2}\right)$, and acetic acid $\left(\mathrm{CH}_{3} \mathrm{COOH}\right)$, whereas at high hydrogen partial pressure, fermentative bacteria produce hydrogen $\left(\mathrm{H}_{2}\right)$, carbon dioxide $\left(\mathrm{CO}_{2}\right)$, ethanol $\left(\mathrm{C}_{2} \mathrm{H}_{5} \mathrm{OH}\right)$, butyric acid $\left(\mathrm{CH}_{3} \mathrm{C}_{2} \mathrm{H}_{4} \mathrm{COOH}\right)$, and propionic acid $\left(\mathrm{CH}_{3} \mathrm{CH}_{2} \mathrm{COOH}\right)$. In case of low hydrogen partial pressure, acetogenic bacteria can transform ethanol, butyric acid, and propionic acid into other organic compounds. In case of high hydrogen partial pressure, organic compounds will not be transformed into other forms; rather, volatile organic acids will accumulate, $\mathrm{pH}$ value will drop, and methane $\left(\mathrm{CH}_{4}\right)$ generation will ultimately be inhibited.

\subsection{Presence of sulphates}

The sulphates present at municipal solid waste landfills usually originate from coal, wood, construction material and waste (drywalls), slag from waste incineration, and fly ash $[11,23]$. The prevalent among the sulphate-reducing bacteria are the Desulfovibrio 
and Desulfotomaculum genera. High activity of these bacteria reduces the amount of available organic matter for methane generation [17].

\subsection{Presence of nutrients}

Nutrients are chemical constituents of food. They are basic chemical ingredients, which are absorbed through the digestive tract to meet the metabolic needs of a living organism. They include macronutrients (proteins, carbohydrates, lipids, and water) and micronutrients (vitamins and minerals). Addition of nutrients as well as metal supplements (e.g. modified natural zeolites - MNZ) positively affects LFG generation [29].

\subsection{Presence of methanogenic inhibitors}

In addition to the inhibition of LFG generation by the presence of oxygen $\left(\mathrm{O}_{2}\right)$, hydrogen $\left(\mathrm{H}_{2}\right)$, and sulphates $\left(\mathrm{SO}_{4}\right)$, there are other inhibiting substances and compounds found in municipal waste landfills. This fact is particularly important from the global perspective in terms of how methane affects climate change. Acetylene $\left(\mathrm{C}_{2} \mathrm{H}_{2}\right)$, ethylene $\left(\mathrm{C}_{2} \mathrm{H}_{4}\right)$, ethane $\left(\mathrm{C}_{2} \mathrm{H}_{6}\right)$, methane chloride $\left(\mathrm{CH}_{3} \mathrm{Cl}\right)$, and methane fluoride $\left(\mathrm{CH}_{3} \mathrm{~F}\right)$ are some of the methanogenic inhibitor compounds, but they also affect the oxidation of methane and its conversion to carbon dioxide and water [21].

\subsection{Pressure}

Most microorganisms grow well and are very active at normal atmospheric pressure, but most of them begin to lose their growth capability in the pressure range from 100 to $500 \mathrm{bar}$, whereas they are completely unable to grow at pressures higher than 500 bar. Increased pressure extends the growth phase and decelerates cell division. Methane emission also greatly depends on atmospheric pressure changes - higher pressure reduces methane emission, whereas lower pressure increases it [30].

\subsection{Properties of landfill cover}

Even though every larger sanitary landfill contains systems for LFG evacuation and/or collection, smaller amounts of the gas still manage to get released into the atmosphere or into the soil, which is a regular occurrence in non-sanitary landfills [31]. The top cover (or cap) composed of inert material is designed so as to block or limit the penetration of atmospheric precipitation into the landfill body and thus prevent uncontrolled LFG emissions. It is recommended that the cap be made of multiple layers, which include, from bottom to top: a gravel layer with a thickness of $0.3 \mathrm{~m}$ for LFG drainage; a geotextile liner with a density of $400 \mathrm{~g} / \mathrm{m}^{2}$ to provide soil stability and protect the bentonite liner, whose permeability coefficient is $3 \times 10^{-11} \mathrm{~m} / \mathrm{s}$; an upper geotextile liner with a density of $400 \mathrm{~g} / \mathrm{m}^{2}$; another gravel layer with a thickness of $0.5 \mathrm{~m}$ for atmospheric precipitation drainage; and the topsoil humus layer with a thickness of $0.5 \mathrm{~m}$. Methane oxidation influenced by microbes in the top cover can be used as a means to control methane emission. Several studies have shown that methane oxidation processes in the landfill cover can efficiently reduce atmospheric emissions of methane. 


\section{CONCLUSION}

All sanitary landfills contain properly placed and operational gas wells because of the significant presence of LFG, i.e. high methane concentrations. This fact suggests that non-sanitary landfills also need to contain gas wells in order to prevent methane accumulation within and outside the landfill body and avoid the formation of explosive mixtures.

Sanitary landfills are usually suitable for all climates and they generate highly toxic leachate and considerable amounts of LFG. There are numerous contributory factors for LFG generation, as summarized below:

- The composition of organic waste components, primarily cellulose, proteins, and lipids, instigates waste decomposition; on the other hand, the lignin/cellulose concentration ratio negatively affects methane generation;

- More recently deposited waste will generate more LFG than the waste that has been lying at the landfill for some time;

- Temperature increases bacterial activity, which leads to an increase in LFG generation;

- Presence of oxygen is considered as an inhibiting factor for methane generation in a landfill;

- Presence and increase of water in a landfill increases gas generation, because moisture stimulates the development of bacteria and the transport of nutrients to every part of the landfill;

- Microorganisms are the most active in areas of optimal $\mathrm{pH}$ values for the key enzymes;

- High hydrogen partial pressure inhibits methane generation.

Based on the analysis of contributory factors, the measurements of LFG components concentrations, and the measurements of wastewater components concentrations, it can be concluded that LFG generation at "Pirot" Regional Sanitary Landfill is intensive, although the landfill has only been operational since 2013.

Acknowledgement: The paper is a part of the research done within the project No III-43014 financed by the Ministry of Education, Science, and Technological Development of the Republic of Serbia.

\section{REFERENCES}

1. Directive 2008/98/EC of the European Parliament and of the Council (2008) on waste and repealing certain Directives, Official Journal of the European Communities L 312, 22.11.2008, p. 3-30.

2. Law on Waste Management ("Official Gazette of the Republic of Serbia", No. 36/2009, 88/2010 and 14/2016).

3. Regulation on Waste Disposal in Landfills ("Official Gazette of the Republic of Serbia", No. 92/10).

4. Brown K.A., Maunder D.H., (1994), Using landfill gas: A UK perspective, Elsevier. Renewable Energy, 5(5-8), 774-781, 1994.

5. Vujić G., Jovičić N., Petrović (Đurović) M., Ubavin D., Nakomčić B., Jovičić G., Gordić D., (2010), Influence of ambience temperature and operational-constructive parameters on landfill gas generation - Case study Novi Sad, Vinča Institute of Nuclear Sciences. Thermal Science, 14 (2), 555-564, 2010.

6. Kolomejceva (Jovanović) L., (2010), Hemija i zaštita životne sredine [Chemistry and Environmental Protection], Belgrade (Serbia), 2010. 
7. Baedecker M.J., Back W., (1979), Hydrogeological Processes and Chemical Reactions at a Landfill, National Ground Water Association. Groundwater, 17(5), 429-437, 1979.

8. Zaman A. U., (2010), Comparative study of municipal solid waste treatment technologies using life cycle assessment method, Springer. International Journal of Environmental Science \& Technology, $7(2), 225-234,2010$.

9. Williams T.P., (2005), Waste treatment and disposal. Second edition. John Wiley \& Sons, 2005.

10. ATSDR, (2001), Landfill Gas Primer - An Overview for Environmental Health Professionals, Department of Health and Human Services, Agency for Toxic Substances and Disease Registry (ATSDR), Division of Health Assessment and Consultation, 2001. http://www.atsdr.cdc.gov/hac/landfill/html/ch2.html

11. Barlaz A. M., Ham R.K., Schaefer D.M., (1990), Methane production from municipal refuse: a review of enhancement techniques and microbial dynamics, Taylor \& Francis. Crit Rev Environ Control, 19(6), 557-584, 1990

12. Milošević L., (2016), Methodological approach to landfill fire risk assessment for the purpose of air pollution evaluation, Doctoral dissertation, University of Nis, Faculty of Occupational safety in Nis, 2016. (In Serbian).

13. Gurijala K.R., Sa P., Robinson J.A., (1997), Statistical Modeling of Methane generation from Landfill Samples, American Society for Microbiology. Applied and Environmental Microbiology, 63(10), 3797-3803, 1997.

14. Farquhar G.J., Rovers F.A., (1973), Gas production during refuse decomposition, Spriger. Air, Water and Soil Pollution, 2(4), 483-495, 1973.

15. Ehrig H.J., (1984), Treatment of sanitary landfill leachate: Biological treatment, International Solid Waste Association. Waste Management Research, 2(2), 131-152, 1984.

16. Gerardi M.H., (2003), The microbiology of anaerobic digesters. John Wiley and sons, Inc. New Jersey, 2003.

17. Christensen T. H., Kjeldsen P., (1995), Landfill Emissions and Environmental Impact: An Introduction, Proceedings of Sardinia 95 - Fifth International Landfill Symposium, Volume 3, Cagliari, Italy, October 1-6, 1995, pp. 3- 12.

18. Milošević L., Mihajlović E., Djordjević A., Radosavljević J., Živković Lj., (2015), Generation and monitoring of methane at a municipal waste landfill, University of Nis. Facta Universitatis, Series: Working and Living Environmental Protection, University of Niš, 12(3), 329-339, 2015.

19. Naranjo N.M., Meima J.A., Haarstrick A., Hempel D.C., (2004), Modelling and experimental investigation of environmental influences on the acetate and methane formation in solid waste. Elsevier. Waste Management, 24(8), 763-773, 2004.

20. Landfill Gas Management Facilities Design Guidelines, prepared by Conestoga Rovers and Associates, Ministry of the Environment (ME), British Columbia (BC), March, 2010. https://www.waste.ccacoalition. org/document/landfill-gas-management-facilities-design-guidelines

21. Chan A.S.K., Parkin T.B., (2000), Evaluation of potential inhibitors of methanogenesis and methane oxidation in a landfill cover soil, Elsevier. Soil Biology \& Chemistry, 32 (11-12), 1581-1590, 2000.

22. Chugh S., Chynoweth D.P., Clarke W., Pullammanappallil P., Rudolph V., (1999), Degradation of unsorted municipal solid waste by a leach-bed process, Elsevier. Bioresource Technology, 69(2),103-115, 1999.

23. Sun Y., Sun X., Zhao Y., (2011), Comparison of semi-aerobic and anaerobic degradation of refuse with recirculation after leachate treatment by aged refuse bioreactor, Elsevier. Waste Management, 31(6), 1202-1209, 2011.

24. Reinhart D.R., McCreanor P.T., Townsend T., (2002), The bioreactor: Its status and future, International Solid Waste Association.Waste Management \& Research, 20 (2), 172-186, 2002.

25. Erses A. S., Onay T.T., (2003), In situ heavy metal attenuation in landfills under methanogenic conditions, Elsevier. Journal of Hazardous Materials, 99 (2), 159-175, 2003.

26. Price G.A., Barlaz M.A., Hater G.R., (2003), Nitrogen management in bioreactor landfills, Elsevier. Waste Management, 23(7), 675-688, 2003.

27. He R., Shen D., (2006), Nitrogen removal in the bioreactor landfill system with intermittent aeration at the top of landfilled waste, Elsevier. Journal of Hazardous Materials, 136(3), 784-790, 2006.

28. White J.K., Beaven R.P., Powrie W., Knox K., (2011), Leachate recirculation in a landfill: Some insights obtained from the development of a sample 1-D model, Elsevier. Waste Management, 31(6), 1210-1221, 2011.

29. Isci A., Demirer G.N., (2007), Biogas production potential from cotton wastes, Elsevier. Renewable Energy, 32(5), 750-757, 2007. 
30. Xu L., Lin X., Amen J., Welding K., McDermitt D., (2014), Impact of changes in barometric pressure on landfill methane emission, John Wiley \& Sons. Global Biogeochemical Cycles, 28(7), 679-695, 2014.

31. Abushammala M.F.M., Basri N.E.A., Irwan D., Younes M.K., (2014), Methane Oxidation in Landfill Cover Soils: A Review, Asian Association for Atmospheric Environment. Asian Journal of Atmospheric Environment, 8(1), 1-14, 2014.

\section{ANALIZA FAKTORA KOJI UTIČU NA STVARANJE DEPONIJSKOG GASA NA SANITARNIM DEPONIJAMA}

Deponovanje otpada je element integrisanog upravljanja otpadom. Valjano izrađeni projekti izgradnje deponije osiguravaju bezbedno odlaganje otpada uz minimalne negativne uticaje na životnu sredinu. U prvom delu rada izvršen je pregled $i$ analiza otpada i deponija $u$ Republici Srbiji. U drugom delu rada, opisani su faktori koji utiču na stvaranje deponijskog gasa. Na osnovu merenja koncentracije komponenata deponijskog gasa i analiziranih uzoraka otpadnih voda sa Regionalne sanitarne deponije „Pirot“ prikazani su uticaji određenog broja faktora na stvaranje deponijskog gasa. U zavisinosti od faktora uticaja, i stvaranjem optimalnih uslova na deponiji se ubrzava proces degradacije otpada $i$ samim tim stvaraju $i$ emituju veće količine deponijskog gasa što dalje ima za cilj i kontrolisano i pravilno upravljanje deponijskim gasom. U ovom radu predstavljene su smernice za kontrolisano upravljanje deponijskim gasom, a samim tim bi se ispunili zahtevi i preporuke kako nacionalnih tako $i$ evropskih propisa.

Ključne reči: otpad, sanitarna deponija, deponijski gas, deponijski filtrat, metan, faktori uticaja 